\title{
TURKISH AND BRICS ENGAGEMENT IN AFRICA
}

\author{
Elem Eyrice Tepeciklioglu* \\ Mohammed Evren Tok** \\ Syed Basher***
}

\begin{abstract}
This article studies the political economy of Turkey's relations with sub-Saharan Africa (SSA) since 2002 while Turkey was under the Justice and Development Party's (AKP) rule. It argues that Turkey has focused its engagement in Africa mostly on humanitarian assistance and the economy. Contextualizing Turkey's relations with SSA vis-à-vis other emerging market economies, especially the BRICS (Brazil/Russia/India/China/South Africa), provides ample insights into the nature of Turkey's engagement in SSA. While Turkey's involvement has some similarities with that of the BRICS, there are greater fundamental and structural differences from how the BRICS established their presence in SSA. These differences mostly find resonance when juxtaposed with the activism of non-governmental actors engaged in humanitarian missions and charity work with trade-related economic investments and activism.
\end{abstract}

Keywords: Turkey, sub-Saharan Africa, political economy, BRICS, trade, humanitarian assistance.

DOI: https://dx.doi.org/10.4314/jsdlp.v8i2.3

\section{INTRODUCTION}

In analysing Turkey's and Sub-Saharan Africa relations, the Brazil/ Russia/India/China/South Africa (BRICS) group provide a suitable

* Research Assistant, International Law Implementation and Research Centre, Yasar University, Izmir/Turkey. E-mail: elem.eyrice@gmail.com. Phone: +902324115651 Fax: +902325707000.

** Assistant Professor and Program Coordinator, Hamad Bin Khalifa University, Doha/Qatar. E-mail: etok@hbku.edu.qa. Phone: +97433120327, Fax: $+97433120327$.

*** Associate Professor, Department of Economics, East West University, Dhaka, Bangladesh. E-mail: syed.basher@gmail.com, Phone: +8809666775577 ext. 140. 
point of comparison. ${ }^{1}$ Not only have they become significant actors in the global governance architecture due to their remarkable levels of economic growth and increasing share of global economic activity but they have also become highly visible in the SSA. For instance, exports and trade with SSA have come to represent a large and significant share of gross domestic product (GDP) in all BRICS countries. Notably, there remain a number of important variations among BRICS nations as well. The emergence and growth of the BRICS suggest major shifts in the global economy that have wide-ranging economic implications. One of these implications has to do with the ways in which changes in the global economic order are taking place. Consequently, the growth of BRICS should be thought of as part of the changing contours of the global economic order. The extent to which SSA can build a mutually beneficial relationship with the emerging powers, particularly the BRICS, will undoubtedly affect its long-term socio-economic development and security.

Emerging powers and developed countries have a long presence in other continents, for instance European countries' competition over access to abundant natural resources of African countries. While economic motivations predominantly explain the contours of this competition, a more inclusive and balanced political economy analysis would include non-economic actors. This is the case where governmental and non-governmental organizations (NGOs) deliver humanitarian aid and engage in capacity building in diverse areas.

Turkey's engagement with Africa is also mostly driven by economic considerations, predominantly by a quest for new export opportunities for Turkish companies. That is, the Turkish government aspires to create markets for Turkish products. Other emerging powers, such as the BRICS, concentrate both on the import or control of Africa's natural resources and on developing market opportunities.

Another example of the contrast with the BRICS is the large investments in Africa's energy and mining sectors. Turkey's interest in Africa's vast natural resources has been limited to a few futile initiatives, such as energy cooperation agreements or declarations of target markets

1 The BRICS, initially the BRIC countries (South Africa was invited to join in April 2011), is a term that was coined by Jim O'Neill in 2001 and is now widely used to exemplify a shift in global economic power away from traditional developed nations. 
in oil-rich Angola. These never resulted in tangible economic outcomes. ${ }^{2}$ Although Turkey has used trade and investment to increase its presence in Africa, ${ }^{3}$ yet, as Bacýk said, "Turkey wants to legitimize its role on the world stage and make out that it is not interested in just trade and economics, but humanitarian issues too". ${ }^{4}$ The current Turkish government has, therefore, been using humanitarian assistance as an initial point of contact with African countries. ${ }^{5}$

In its humanitarian diplomacy approach, the Turkish government uses official, civic and business channels. Whereas previous aid activities were mostly initiated at state level, public institutions have begun to increasingly work in collaboration with Turkish civil society organizations, most of which are religiously motivated. Their involvement has diversified the actors involved in the foreign policy domain, helping to strengthen Turkey's soft power instruments in various regions. ${ }^{6}$ This humanitarian involvement has also initiated and facilitated trade relations with African countries. As business groups with interests in African countries have financed the activities of civil society organizations operating in the humanitarian domain, so those organizations have laid the ground for these businesses to enter the African markets. Although the government is still the dominant actor in this field, the role of NGOs in providing humanitarian aid and development assistance is increasing.

The BRICS have pursued somewhat different strategies regarding humanitarian aid, capacity building and development-related activities. However, those initiatives of individual BRICS countries are not

2. David Shinn, “Turkey's Engagement in Sub-Saharan Africa: Shifting Alliances and Strategic Diversification" (2015) Chatham House, The Royal Institute of International Affairs Research Paper.

3 Stratfor, "Turkey's Feud With Gülenists Could Upset Its Africa Policy" (19 April 2014) < https://worldview.stratfor.com/article/turkeys-feud-gulenists-couldupset-its-africa-policy>accessed 21 September 2017.

4 Alexander Christie-Miller, "Turkey takes lead in rebuilding Somalia" The Christian Science Monitor (5 June 2012) < http://www.csmonitor.com/World/MiddleEast/2012/0605/Turkey-takes-lead-in-rebuilding-Somalia >accessed 20 October 2015.

5 Abdirahman Ali, “Turkey's Foray into Africa: A New Humanitarian Power?' (2011) 13 Insight Turkey 65.

6 Pinar Akpinar, "Turkey's Peacebuilding in Somalia: The Limits of Humanitarian Diplomacy" (2013) 14 Turkish Studies 735; Mehmet Özkan and Birol Akgün, "Turkey's Opening to Africa" (2010) 48 The Journal of Modern African Studies 525. 
homogeneous. For instance, while China offers versatile collaborations through universities and the establishment of Confucius Institutes that operate as joint ventures between Chinese and foreign universities, Russia and India's efforts have mostly relied on the BRICS Civil Society Forum, introduced as the Civil BRICS Forum under Russia's 2015 presidency.

The major findings of this study are that Turkey's soft power initiatives in SSA have been an important complement to its official diplomatic and developmental efforts as well as its business and political interests in SSA. Furthermore, our findings also reveal that the interests of other emerging powers, such as the BRICS in SSA, follow an entirely different approach from Turkey's engagement in SSA.

As the article will illustrate in more detail, each approach has its pros and cons. For instance, the reduced economic impact of the Turkish approach is associated with the sectors penetrated, whereas BRICS countries have been way more successful in unleashing the market capacity and potential in SSA on a more global basis. Moreover, the current rift between the AKP and the Gülen Movement, the latter of which formerly complemented Turkey's African opening, might affect prospects for Turkey-SSA relations and its political economy. The movement was very active in African countries through its schools, charity activities and business relations. However, the cooperation between those two parties shattered after the emergence of an alleged corruption scandal dating from 17 to 25 December 2013. ${ }^{7}$ President Recep Tayyip Erdogan then called on African leaders to close Gülenaffiliated schools, arguing that the movement used those schools as a cover for their "dangerous actions" and promising that his government would replace those schools abroad with ministry schools. ${ }^{8}$ However, it will require some time and effort for the government to replace the

7 On 17 December 2013, Turkish prosecutors brought corruption charges against key government officials and their family members. The AKP-led government blamed the Gülen movement for the corruption investigation and accused the movement of infiltrating state structures, especially the judiciary and police force, setting up a "parallel state" and planning to bring down the government through such allegations. On 15 July 2016, a coup d'état was attempted against the government which is allegedly supported by the movement.

8 Addis Ababa, "Erdogan vows to replace Gülen schools abroad with Turkish ministry schools" Hürriyet Daily News (22 January 2015) <www.hurriyetdaily news.com/erdogan-vows-to-replace-Gülen-schools-abroad-with-turkishministry-schools.aspx?pageID $=238 \& \mathrm{nID}=77299 \&$ NewsCatID $=338>$ accessed 13 June 2015. 
Gülen network in African countries with government-sponsored initiatives.

Comparing Turkey and the BRICS illustrates, with few exemptions, that the BRICS' economic gains, whether actual or potential, have primacy over non-governmental and civil forms of engagement. On the other hand, Turkey pursued a relatively more balanced perspective in terms of its humanitarian efforts and economic concerns. As Ozkan (2012) argued, Turkey's status as a new influential actor or just a "passer-by" in the African context is yet to be explored. Comparing Turkey with BRICS and then delving into Turkey's historical and contemporary focus on Africa, we argue, constitute sound starting points to bringing a relatively more balanced and realistic long term perspective to the discourse.

The article is divided into four major sections. It first discusses how Turkey's humanitarian and development assistance, provided through governmental and non-governmental channels, has contributed to the country's positive image as a new-comer in Africa. This sectional so compares Turkish initiatives in humanitarian domain with that of BRICS with a special focus on the religious dimension of Turkish aid and the active involvement of Turkish NGOs in contributing to the bilateral humanitarian diplomacy efforts of the government. The second section then analyses Turkey's engagement in Africa in economic terms by comparing it with the economic role of BRICS in the same region. This section highlights that Turkey's involvement in economy and finance is limited especially when compared to BRICS' even though Turkey has a potential for more sustained engagement. Section 3 continues the discourse in the economic context, while the last section concludes the discussion.

\section{HUMANITARIAN DIPLOMACY}

Turkey's desire to become a more active player in changing world politics and responding to the demands of Turkish business for new markets resulted in its adopting a humanitarian diplomacy. The increasing involvement of Turkish civil society in foreign policy-making process has also contributed to Turkey's emergence as an influential actor in providing humanitarian $\operatorname{aid}^{9}$ and an emerging trade partner for Africa.

9 Pinar Akpinar and Bülent Aras, "Workshop Report: International Humanitarian NGOs and Emergency Aid" (Istanbul Policy Centre, Istanbul, 2015). 
Although humanitarian diplomacy means more than humanitarian aid, ${ }^{10}$ aid is an important element of this human-centred diplomacy. For example, in 2013, Turkey became the largest donor in terms of humanitarian aid generosity. According to the Global Humanitarian Assistance Report 2014, Turkey distributed US\$1.6 billion in humanitarian aid, making it the third largest donor state after the United States and the United Kingdom. ${ }^{11}$

It is also important to note that 50 per cent of Turkey's official development assistance went to humanitarian assistance while 24.7 per cent of Turkish development cooperation projects were related to Africa. In 2013, Turkey distributed development assistance worth US $\$ 4.347$ billion, with nearly 75 per cent delivered through public entities as official development assistance, US $\$ 820$ million by the private sector as direct investment, and US $\$ 280$ million by nongovernmental organizations as humanitarian assistance. ${ }^{12}$

In 2014, Turkey provided US\$383 million in development aid to sub-Saharan African countries, which constituted one-third of Turkey's overall development assistance. ${ }^{13}$ In comparison, the aid flows of BRICS to developing countries significantly lag behind other donors. When Turkey became the third largest donor state in 2013, no BRICS country featured among the top 20 government contributors. China is the leading BRICS country in terms of the size and scope of foreign assistance. The amount of development assistance China provided between 2009 and 2010 corresponded to the total volume of aid provided by other BRICS countries. ${ }^{14}$

10 Ahmet Davutoglu, “Turkey's Humanitarian Diplomacy: Objectives, Challenges and Prospects" (2013) 41 Nationalities Papers: The Journal of Nationalism and Ethnicity, 865.

11 Global Humanitarian Assistance, "Global Humanitarian Assistance Report" (2014) <http://devinit.org/wp-content/uploads/2014/09/GlobalHumanitarian-Assistance-Report-2014.pdf >accessed 1 August2016.

12 Basbakanlik Kamu Diplomasisi Koordinatörlügü, "Uluslararasi yardimlarda "en cömert ülke" unvanini tasiyan Türkiye'nin yardým seferberligi sürüyor" (2014) <http://kdk.gov.tr/haber/turkiyenin-dis-yardimlari-2013/494>accessed 11 August2016.

13 Mevlüt Çavusoglu, "2016 Yili Basinda Dis Politikamiz” (2016). T.C. Disisleri Bakanligi.

14 Daniel Poon, "South-South Trade, Investment, and Aid Flows" (The North-South Institute Policy Brief 2013) < http://www.nsi-ins.ca/wp-content/uploads/ 2013/06/2013-South-South-Trade-Investment-and-Aid-Flows.pdf $>$ accessed 7 August 2016. 
Turkey's foreign aid policy became better coordinated with the establishment of Turkish Cooperation and Coordination Agency (TIKA) in 1992. The organization later became the Turkish government's principal aid agency. TIKA was initially established to coordinate operations in Central Asia and Caucasia. In this initial phase, Asia was the priority area, and Africa the least important. In line with government policy to improve relations with African countries TIKA expanded its area of action to Africa in 2005. Currently, 11 of its 40 programme offices are located in African countries. ${ }^{15}$ TIKA now places particular importance on Africa by developing programmes primarily in education, health and agriculture. Whereas only 28 of 562 TIKA projects were devoted to Africa in $2005,{ }^{16}$ this number increased to 525 or 33.7 per cent of its 1,800 projects in 2013. ${ }^{17}$ TIKA now operates in 28 African countries with Somalia and Ethiopia being among the major recipients. ${ }^{18}$ TIKA's activities enhanced Turkey's image and visibility in those countries. As a senior director at TIKA noted, "Turkish businessmen follow TIKA in the Africa region. When TIKA opens up an office in one African country, Turkish Airlines starts flights to these destinations, which increases the interest of businessmen and simplifies their operations." 19

In addition to TIKA, some ministries also deliver humanitarian aid to African countries while AFAD (Prime Ministry Disaster and Emergency Management Authority) provides disaster and emergency relief, mostly in coordination with other public institutions, including the Ministry of Health and Foreign Ministry. Especially through the Ministry of Health, TIKA and Istanbul Metropolitan Municipality, the government delivers medical relief to African countries.

15 TIKA, "Africa" (2015) < http://www.tika.gov.tr/upload/2015/Prestij/ Afrika_Ing.pdf $>$ accessed 4 August 2016.

16 TIKA, "Faaliyet Raporu" (2005) < http://www.TIKA.gov.tr/upload/ oldpublication/faaliyet-raporu-2005.pdf $>$ accessed 21 September 2017.

17 TIKA, Annual Report 2013 (2013) < http://www.tika.gov.tr/upload/ publication/ TIKA\%20ANNUAL\%20REPORT\%202013.pdf $>$ accessed 4 August 2016.

17 TIKA, "TIKA Afrika'nin 28 Ülkesinde Faaliyet Gösteriyor" (2015) < http:// www.tika.gov.tr/tr/haber/tika_afrika_nin_28_ulkesinde_faaliyet_gosteriyor_ (video_haber)-15825>accessed 4 August 2016.

19 Pinar Ipek, "Ideas and Change in Foreign Policy Instruments: Soft Power and the Case of the Turkish International Cooperation and Development Agency" (2015) 11 Foreign Policy Analysis, 173. 
Diyanet (Directorate of Religious Affairs) also provides humanitarian assistance to African countries. Diyanet's role in foreign-policy making has accelerated during AKP government. In order to develop religious ties with African countries and increase Turkey's influence in the region, Diyanet establishes mosques in some countries through its mosque-building programme, provides scholarships to Muslim students from African countries and organizes meetings with Muslim religious leaders from all over Africa. In 2012, Mehmet Görmez became the first head of religious affairs to visit Africa. Religion has become a key element of Turkey's active involvement in Africa while this religious dimension is nearly absent in BRICS's engagement in the continent. Moreover, many Turkish civil society organizations and religious groups such as the Gülen movement, Hüdayi Foundation and Süleymancilar have also employed religion in order to legitimize their activities by focusing mostly on the educational field. ${ }^{20}$

Other non-governmental organizations operating in African countries include the Cansuyu Charity and Solidarity Foundation, IHH (Humanitarian Relief Foundation), Yeryüzü Doktorlari (Doctors Worldwide), Kimse Yok Mu (Is Anybody There?), Deniz Feneri Association (the Lighthouse Association), the Nile Foundation, Yardimeli Dernegi (the Helping Hands Foundation), the Hasene Foundation, DUNYEV (the Foundation for World Orphans) and the Besir Foundation. The former two foundations mainly deliver emergency aid activities and assistance to those suffering from conflicts, wars, crises and natural disasters.

Deniz Feneri is one of the largest Turkish NGO, delivering humanitarian assistance in 18 African countries, while Doctors Worldwide provides humanitarian and medical aid in 10countries from Africa. Kizilay (Turkish Red Crescent), Turkey's oldest non-governmental organization, also operates in different African countries. For example, it has been the most active Turkish NGO operating in Somalia. After the UN declared a famine in two areas within Somalia in 2011, Kizilay established the Somalia Delegation Presidency in the same year and started a relief campaign. In 2011, 60 per cent of all NGO assistance was distributed for alleviating famine in Somalia. In 2012, Africa was still the leading regional recipient of Turkish NGO assistance with US\$68.54 million, followed by the Middle East with US\$42.07 million,

20 Mehmet Özkan, “Turkey's Religious and Socio-Political Depth in Africa” (2013) Emerging Powers in Africa, LSE IDEAS Special Report. 
and South and Central Asia with US\$27.54 million. However, following recent developments in Syria, the Middle East replaced Africa as the major recipient of NGO assistance in 2013 when US\$113.38 million was distributed to the Middle East and Syria received 40 per cent of all NGO assistance. Aid to Africa also increased to US\$93.22 million, with Somalia again being the major recipient in $2013 .^{21}$

Turkish humanitarian assistance often comes with no strings attached. On the other hand, concessional aid or grants such as "loansfor-oil" represents an important component of China's aid policy. It is not uncommon that Chinese government carries out a development project in exchange for access to rights to natural resources or mines. India also provides development assistance in exchange for the purchase of Indian goods. ${ }^{22}$ It should also be noted that both the Turkish government and civil society groups mostly operate on the ground and coordinate their activities with local NGOs. For example, in Somalia, Turkish NGOs coordinated with Somalian authorities and worked in collaboration with local partners to serve otherwise inaccessible regions. It has been asserted, therefore, that Turkish engagement in Somalia changed the aid landscape in the country. ${ }^{23}$

This was in contrast with other donor countries delivering their aid through Nairobi-based international organizations. BRICS' resort to global multilateral channels with an emphasis on South-South cooperation is also opposed to Turkey's bilateral humanitarian diplomacy with the increasing role of Turkish NGOs. India, for example, prefers to use multilateral channels, especially in complex humanitarian emergencies with only a few Indian NGOs being active abroad. ${ }^{24}$ Russia is also hesitant to work with NGOs and thus channels most of its

21 TIKA, "Turkish Development Assistance 2012" (2013) < http://www.tika.gov.tr/ upload/oldpublication/TurkishDevelopmentAssistance2012.pdf $>$ accessed 21 September 2017; TIKA, "Turkish Development Assistance 2013” (2013) < http:/ /www.tika.gov.tr/upload/publication/KYR_FRAE_2013_uyg9.pdf > accessed 4 August 2016.

22 Poon (n 14).

23 Saferworld, "Turkey and Somalia: Making Aid Work for Peace" (20 March 2015) <http://www.saferworld.org.uk/oldsite/resources/view-resource/892-turkeyand-somalia-making-aid-work-for-peace> accessed 21 September 2017.

24 Claudia Meier and C.S.R. Murthy, "India's Growing Involvement in Humanitarian Assistance" (2011) GPPi Research Paper 13; Gwenn Price, "Diversity in Donorship: The Changing Landscape of Official Humanitarian Aid" HPG Background Paper (London, 2005). 
humanitarian aid through multilateral humanitarian agencies. ${ }^{25}$ Chinese NGOs also play only a marginal role in delivering Chinese external assistance with only a few of their NGOs being involved in aid projects. ${ }^{26}$ In contrast, the focus of Brazilian aid is technical assistance, especially for health and agriculture projects, and technology transfer from Brazilian institutions. South Africa's presence is mostly concentrated in Southern Africa, but its financial capacity in development assistance and humanitarian aid is not comparable to that of other BRICS countries.

As discussed, Turkish business groups have supported the aid activities of civil society organizations to facilitate trade relations. The lobbying of Turkish companies and business associations with large foreign investments abroad also played an important part in the development of opening policy to Africa. ${ }^{27}$ As Fadi Hakura from Chatham House notes, the incumbent AKP government has close ties with business associations looking for new markets, especially those representing the Anatolian Tigers. ${ }^{28}$ Among the many involved in African countries, the Gülen-affiliated TUSKON (the Confederation of Businessmen and Industrialists of Turkey), founded in 2005, was once the most active. Shortly after its establishment, TUSKON started to organize annual trade bridge meetings with representatives from African countries.

Notably, even before the recent split between the movement and the AKP government, TUSKON had to compete with other actors, such as DEIK (Foreign Economic Relations Board), which has an official legal status, TIM (Turkish Exporters Assembly), the umbrella organization for exporting firms, and MUSIAD (Independent Industrialists and Businessmen Association). Prior to the struggle between the government and the Gülen-movement, the former, along with the conservative business community, represented mostly by MUSIAD, and the Gülen-inspired business community, represented

25 Anna Brezhneva and Daria Ukhova, Russia as a Humanitarian Aid Donor (OXFAM Discussion Paper2013).

26 Yin Sun, "China's foreign aid reform and implications for Africa" (Brookings 2015) < http://www.brookings.edu/blogs/africa-in-focus/posts/2015/07/01china-foreign-aid-africa-sun> accessed 15 August 2016.

27 Kemal Kirisçi, "The Transformation of Turkish Foreign Policy: The Rise of the Trading State" (2009) 40 New Perspectives on Turkey 29.

28 Richard Lough,"Turkey Tries Out Soft Power in Somalia" (Reuters, 3 July 2012) <http://www.reuters.com/article/2012/06/03/somalia-turkeyidUSL5E8GP2LP20120603> accessed 7 August 2016. 
mostly by TUSKON, constituted a power triangle in providing humanitarian assistance. ${ }^{29}$ However, following the rift between the government and the Gülen movement, MUSIAD and TIM are taking over TUSKON's role in Africa. This conflict also resulted in an increase in the activities of DEIK now having business councils in 30 African countries. ${ }^{30,31}$

As seen, one of the most important features of Turkey's foreign policy activism and its recent involvement in Africa is this significant participation of non-state actors in foreign policy-making. This multiplicity of actors involved in foreign policy-making towards Africa is visible in the Turkish context. At the same time, Turkish aid, as for that of other traditional and emerging powers in Africa, serves the country's economic interests. However, as Binder notes, ${ }^{32}$ the Turkish government still lacks an official policy on its priorities for humanitarian aid. Moreover, most state funding is now channelled to Syria. Although economic success and political transformation increased Turkey's attractiveness in various regions, including Africa, it is possible that the deteriorating economic situation and fears about the AKP government's growing authoritarianism will have a significant impact on perceptions of Turkey and its credibility in the region.

\section{ECONOMIC TRENDS}

This section highlights Turkey's involvement with its counterparts in sub-Saharan Africa in the areas of economy and finance. Turkey's role in SSA is also compared with those of BRICS to emphasize the enormous opportunities that remain to be exploited in many parts of sub-Saharan Africa.

Turkey's trade with SSA has increased steadily between 2001 and 2015, creating a basis for Turkish authority to launch measures for furthering trade between the two regions. Trade between Turkey and

29 Andrea Binder, “The Shape and Sustainability of Turkey's Booming Humanitarian Assistance" (The Graduate Institute, Geneva, Articles and Debates 2014) 5.2.

30 DEIK was established in 1986 to coordinate the private sector's foreign economic relations while Law No. 6552, enacted on September 2014, further empowered it, giving its board full responsibility for "managing the foreign economic relations of the Turkish private sector."

31 DEIK, "DEIK Info"<http://en.deik.org.tr/287/DeikHakkinda.html> accessed 4 March 2016.

32 Binder (n 29). 
SSA climbed from around US\$1 billion in 2001 to over US\$5 billion in 2015. Exports constitute the important driver of economic relationship between the two regions. As a share of its total exports, Turkey more than doubled its exports to SSA from 0.97 per cent in 2001 to 2.24 percent in 2015 (Table 1). On the other hand, despite the rise in Turkey's imports from SSA in value terms, as a share of its total imports, Turkey's imports from SSA have fallen from 1.70 percent in 2001 to about 1 percent in 2015 (Table 2). These figures may appear disappointing partly because they fall short of government's growth targets. ${ }^{33}$

Table 1. Exports to SSA by BRICS and Turkey (\% of total exports)

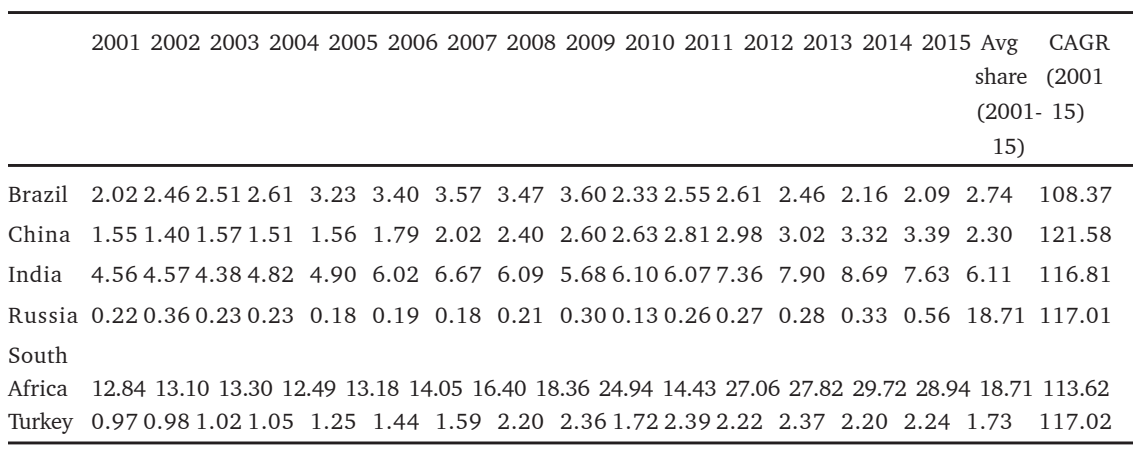

Notes: Authors' calculations based on Direction of Trade Statistics, IMF, CAGR refers to compound annual growth rate. Numbers are reported in percentage points.

Table 2. Imports from SSA by BRICS and Turkey (\% of total exports)

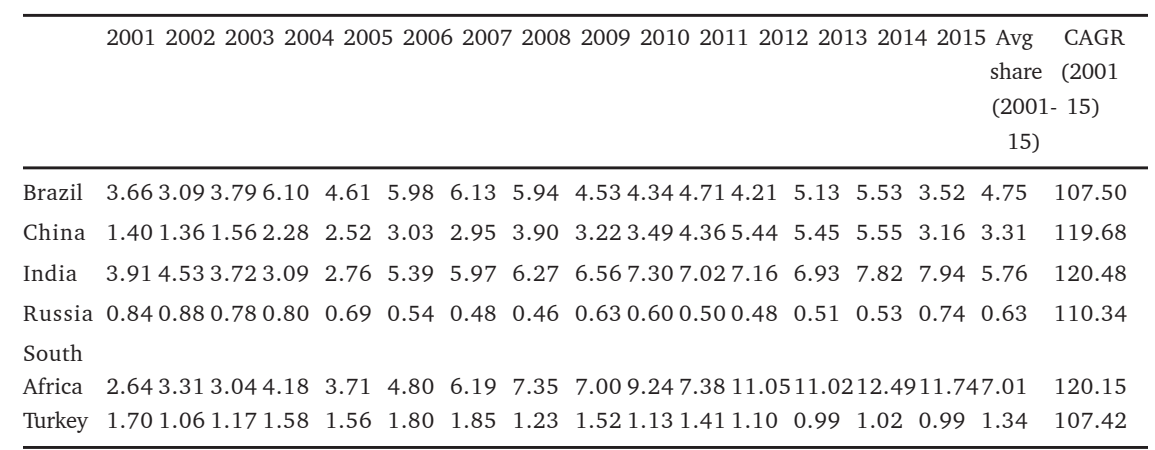

Notes: Authors' calculations based on Direction of Trade Statistics, IMF, CAGR refers to compound annual growth rate. Numbers are reported in percentage points.

33 Shinn (n 2). 
Compared to BRICS (and barring Russia), Turkey's exports and imports with SSA appear small. Needless to say, among the BRICS nations, South Africa is the most significant player in SSA due to its geographical proximity and political ties with the 48 SSA countries. The other four BRIC countries have their own drivers for engaging with SSA. Trade between India and Africa dates back to thousands of years when Indian traders sailed to the east coast of Africa in search of raw materials and intermediate goods. ${ }^{34}$ Brazil too has a strong historical and cultural links with Africa due to its colonial influence on the continent from the sixteenth to the early nineteenth century. ${ }^{35}$ Whereas, China's concerns in Africa are more than accessing the latter's minerals, China is the most significant business partner among emerging counties. ${ }^{36}$ Though a relative newcomer, Russia's engagement in Africa is growing across various spheres ranging from direct investments to peace-keeping. ${ }^{37}$ In comparison, Turkey's growing relationship with Africa has been aided by a series of public initiatives such as Turkey's joining the African Development Bank, signing bilateral investment treaties with 12 SSA countries and, most importantly, opening up new embassies in African continent. ${ }^{38}$

In the aftermath of the Great Recession of 2008-2010, world trade growth has been remarkably sluggish. ${ }^{39}$ It is instructive, therefore, to look at Turkey's growth of exports and imports with SSA, compared with those of BRICS. Table 3 reports the annual average growth rate (AAGR) of trade with SSA before and after the financial crisis. Whereas Turkey posted the highest level of export growth with SSA before the crisis, export growth declined sharply than other BRICS countries

34 KPMG, "India and Africa - Collaboration for Growth" (2015) < https:// assets.kpmg.com/content/dam/kpmg/pdf/2015/10/India-AfricaSummit2015.pdf $>$ accessed 21 September 2017.

35 World Bank, "Bridging the Atlantic: Brazil and Sub-Saharan Africa, South-South Partnering for Growth" (Washington DC., 2012).

36 The Economist, "More than minerals" (23 March 2013) <http:// www.economist.com/news/middle-east-and-africa/21574012-chinese-tradeafrica-keeps-growing-fears-neocolonialism-are-overdone-more $>$ accessed 15 September2016.

37 Alexandra Arkhangelskaya and Vlademir Shubin, "Is Russia Back? Realities of Russian Engagement in Africa" London School of Economics and Political Science(London, 2013).

38 Mehmet Özkan, “Turkey’s Rising Role in Africa” (2010) 9 Turkish Policy Quarterly 93; Shinn (n 2).

39 Christina Constantinescu, Aiditya Mattoo and Michele Ruta, "Slow trade" (2014) 51 Finance \& Development, 39. 
(except Brazil) after the global financial crisis. A similar pattern can be seen in Turkey's imports from SSA, which slowed remarkably after the crisis. These figures in part reflect a broader pattern of Turkey's slower total trade growth with the rest of the world due to weak growth in trading partners (particularly Europe) and increasing unit labour cost at home. ${ }^{40}$ Furthermore, a real effective exchange rate overvaluation thanks to the positive inflation differential with trading partners contributed to Turkey's loss of external competitiveness in recent years. ${ }^{41}$

Table 4 reports exports and imports by Turkey with SSA in 20 broad product categories in 2015. To save space, figures are not shown for other years and for BRICS countries, but they are discussed here to facilitate comparison. As can be seen, consumer products made up the bulk (around 43 per cent) of Turkey's exports to SSA in 2015 followed by intermediate goods (33 per cent) and capital goods ( 21 per cent). Occasionally, though, exports of intermediate products stay on top of Turkey's exports to SSA. Exports of consumer goods to SSA also appear as the major product exported by India (62 per cent), China (48 per cent), and South Africa (39 per cent). Whereas, raw materials and vegetable are major export items of Russia to SSA, the product categories of Turkey's imports from SSA are much less diversified. Raw material is the single largest import category averaging 56 per cent of total imports from SSA during 2015. As a result, Turkey ran a raw material trade deficit with SSA of US $\$ 1.1$ billion in 2015. Similar to Turkey, the BRICS nations also import raw materials heavily from SSA with Brazil (75 per cent) topping the list followed by India (69 per cent), South Africa (67 per cent), China (55 per cent), and Russia (54 per cent).

Table 3. Average annual growth rate (AAGR) of trade with SSA (\%)

\begin{tabular}{lcccc}
\hline & \multicolumn{2}{c}{ Exports to SSA } & \multicolumn{2}{c}{ Imports from SSA } \\
& $\begin{array}{c}\text { Pre-crisis } \\
(2001-2008)\end{array}$ & $\begin{array}{c}\text { Post-crisis } \\
(2009-2015)\end{array}$ & $\begin{array}{c}\text { Pre-crisis } \\
(2001-2008)\end{array}$ & $\begin{array}{c}\text { Post-crisis } \\
(2009-2015)\end{array}$ \\
\hline Brazil & 28.78 & -5.90 & 32.87 & -0.21 \\
China & 35.89 & 13.19 & 46.37 & 9.49 \\
India & 28.29 & 12.06 & 42.36 & 10.69 \\
Russia & 31.85 & 20.91 & 22.09 & 2.36 \\
South Africa & 18.28 & 22.68 & 41.72 & 11.17 \\
Turkey & 38.78 & 4.22 & 25.23 & 0.11 \\
\hline
\end{tabular}

Notes: Authors' calculations based on Direction of Trade Statistics, IMF. Numbers are reported in percentage points.

40 IMF, “Turkey: 2016 Article IV Consultation” (Country Report No. 16/104, 2016). 41 IMF, “Turkey: 2014 Article IV Consultation” (Country Report No. 14/329, 2014). 
Table 4. Product exports and imports by Turkey with Sub-Saharan Africa in 2015.

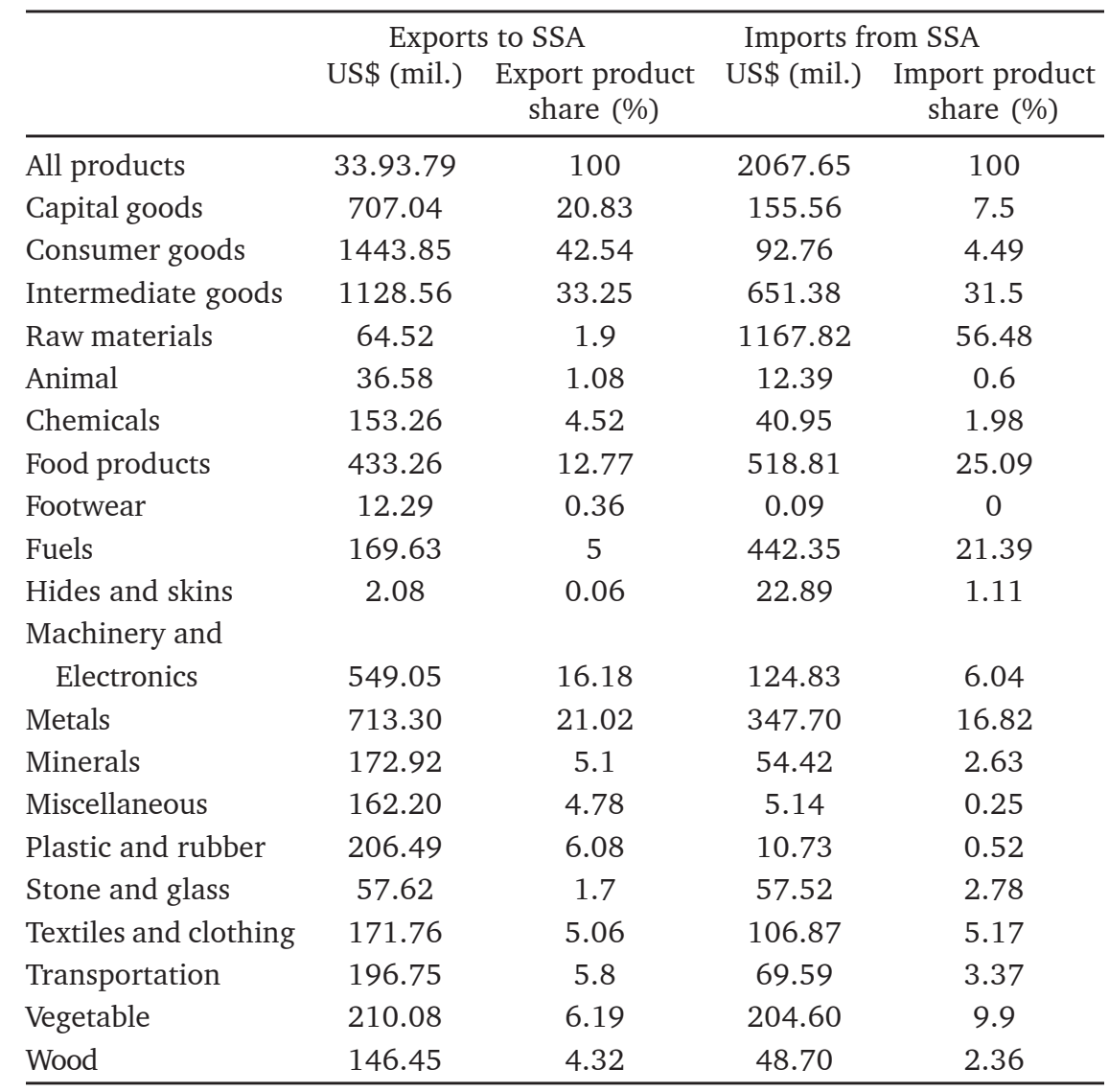

Source: World Integrated Trade Solution (WITS) Database, World Bank.

Table 5. Total FDI inflows in Africa (US\$ billion)

\begin{tabular}{llllllllllllllll}
\hline & 2003 & 2004 & 2005 & 2006 & 2007 & 2008 & 2009 & 2010 & 2011 & 2012 & 2013 & 2014 & 2015 & Total \\
\hline Brazil & 2.9 & 0.0 & 0.0 & 0.0 & 1.8 & 2.2 & 0.3 & 0.8 & 1.2 & 0.0 & 0.0 & 0.1 & 0.3 & 9.7 \\
China & 6.0 & 0.2 & 0.9 & 2.4 & 1.8 & 9.1 & 2.9 & 0.8 & 1.8 & 1.8 & 0.3 & 6.1 & 2.3 & 36.5 \\
Russia & 0.6 & 0.8 & 0.1 & 0.1 & 0.6 & 2.6 & 1.1 & 0.1 & 0.7 & 0.1 & 1.7 & 0.1 & 4.0 & 12.6 \\
South & & & & & & & & & & & & & & \\
Africa & 1.8 & 1.8 & 0.3 & 1.0 & 0.9 & 1.7 & 6.8 & 3.4 & 4.7 & 1.3 & 5.6 & 4.8 & 2.0 & 36.2 \\
Turkey & 0.1 & 0.1 & 0.0 & 0.0 & 0.1 & 0.0 & 0.6 & 0.6 & 0.1 & 1.3 & 2.3 & 0.4 & 0.2 & 5.9 \\
\hline
\end{tabular}

Notes: African Economic Outlook, 2016. 
In recent years, Africa's attractiveness as an investment destination has become more visible to corporations and countries alike. In 2015, foreign direct investment in Africa increased by 16 per cent. ${ }^{42}$ Compared to BRICS countries, the amount of Turkish investment in Africa is modest (Table 4 and 5). Interestingly, although India and China have invested in far greater amounts, they have not necessarily created many jobs a gap that is being filled by Turkey. According to African Investment Report (2015), ${ }^{43}$ Turkey ranks as the top investing country in Africa by job creation generating 16,593 jobs in 2014 against 10,811 by China and 6,193 by India. However, investment flows into Africa remain volatile due to a combination of external factors such as economic slowdown in emerging economies and the weak recovery in the European countries, declining oil and metal prices, and domestic factors like terrorist activity and deteriorating security in some Sahel countries.

Over the last decade, many African governments have relied on market mechanisms such as bond issuance to finance domestic debt. At the same time, foreign investors are increasingly willing to fund SSA frontier markets due to a comparatively higher return and improved credit ratings of African countries. This and other push and pull factors contributed to the surge in private portfolio capital flows. ${ }^{44}$ Unlike longterm investments such as FDI, data on portfolio flows is scanty and often reported as missing. Nevertheless, based on the CPIS dataset of the IMF, the accumulated portfolio flows to SSA over the 2001-2015 period reached US $\$ 315$ million by India, ${ }^{45}$ followed by Russia (US $\$ 240$ million) and Brazil (US\$210 million). Data for China was not available. Compared to these figures, Turkey only invested US $\$ 8$ million in SSA frontier markets over the same period.

A final area of cooperation between Turkey and SSA is on labour movement. Over the past years, Turkey is being transformed from a transit country for sub-Saharan Africans on their way to Europe to a

42 OECD, "African Economic Outlook" (2016), 55, <https://www.afdb.org/ fileadmin/uploads/afdb/Documents/Publications/AEO_2016_Report_ Full_English.pdf $>$ accessed 21 September 2017.

43 fDiIntelligence, "Africa Investment Report"(London, 2015), 7, <http:// www.africanbusinesscentral.com/wp-content/uploads/2016/01/The-AfricaInvestment-Report-2015-fDi-Intelligence-Report.pdf $>$ accessed 21 September 2017.

44 IMF, "Managing Volatile Capital Flows: Experiences and Lessons for Sub-Saharan African Frontier Markets" (African Department 14/01, 2014).

45 The figures for India are based on the 2004-2015 period. 
new destination for sub-Saharan Africans migrants. ${ }^{46}$ This represents a radical break with the past where all sub-Saharan Africans would aspire to migrate to Europe by all means following the legacy of colonization. ${ }^{47}$ Based on in-depth interviews with SSA migrants in and around Istanbul, Saul (2014), De Clerck (2015) and Schapendonk (2015) present new evidence that complement the findings of earlier studies illustrating the growing aspirations of African migrants towards Turkey as one of many possible destinations, attributed to both the increased economic vitality in many regions of Africa and Turkey's changing relationship with SSA countries. Needless to say, recent regional events in the Middle Eastern countries have further contributed to Turkey's increasing role as a shock absorber of unfettered migration flows.

To sum up, being at the crossroads between Asia and Europe, Turkey is well placed to take advantage of SSA's rapid growth in recent years, while SSA has much to gain from intensifying its ties with Turkey's rise as a global economic power. Turkey is well placed for various reasons, but predominantly the cultural rapprochement between the Muslim countries (or Muslim majority) in SSA and Turkey's Presidency has been paving the way to cultivate business interests. Still, a proper evaluation of this relatively new commercial relationship between Turkey and SSA falls short because available evidence is sparse to confidently estimate the economic implications of the new trend. Yet the evidence presented here is positive, suggesting the potential for more sustained and longer-term engagement.

For longer-term engagements, although it is beyond the scope of this study, as a policy proposal, it is imaginable that given Turkey's strategic partnership with Qatar and other Gulf Cooperation Council (GCC) states (Kingdom of Saudi Arabia, Oman, the United Arab Emirates, Kuwait, and Bahrain), could enhance in the future triangular cooperation mechanisms between SSA, Turkey and the GCC. Given the historical and contemporary connections between GCC and the East African states, such as Ethiopia, Eritrea, Sudan, Mozambique and

46 Helene Marie-Lou De Clerck, “Europe Is No Longer the Only 'El Dorado’ For SubSaharan Africans: The Case of Contemporary Senegalese Migration to Turkey" (2015) 4 Migration and Development 272; Joris Schapendonk, "African Passage through Istanbul" in Martin van der Velde and Ton van Naerssen (eds), Mobility and Migration Choices: Threshols to Crossing Borders (Routledge 2016); Mahir aaul, "A Different Kargo: Sub-Saharan Migrants in Istanbul and African Commerce" (2014) 43 Urban Anthropology 143.

47 De Clerk (n 46). 
Djibouti, there are various opportunities that could be utilized by this triangular engagement.

\section{CONCLUSION}

It is debatable whether the BRICS and even Turkey are benevolent actors and the saviours of SSA from the historical accounts of dependencies. In very broad terms, BRICS' interest has been more divergent than Turkey's. Turkish interest in SSA is often identified with both a humanitarian perspective and the continent's commercial potential. ${ }^{48}$ However, the actual impact of Turkey's humanitarian efforts has been relatively limited in terms of both the local impact on capacity building and economic collaboration emerging from the various forms of solidarity cultivated between African countries and Turkey. Both BRICS and Turkey have explicitly addressed the African growth model and underlined the structural problems of African countries.

It has been noted that the two varied approaches have their strengths and weaknesses in relation to SSA. While BRICS involvement is more geared towards extractive industries and natural resource investments in general, Turkey's approach has been embroiled with social and political concerns and expectations. While BRICS offer diverse economic opportunities with a significant long-term social and environmental cost, Turkey's approach posits itself as a broader perspective.

A crucial area of divergence between the BRICS and Turkey concerns the sectorial composition of their vested interests. BRICS countries have a wide range of interests, predominantly in extractive industries, oil/gas reserves and other minerals, and water/land resources, whereas Turkish interests have been limited to manufacturing and services, with few exceptions.

For instance, the most visible presence of the BRICS in Africa has undoubtedly been in minerals. Since 2000, China in particular has established a series of resource-backed deals, in which dams, power plants and other infrastructure projects are exchanged for rights to oil, iron ore, copper, cobalt, and other mineral resources contrary to the

48 Fehim Tastekin, “Turkey's Africa Policies Blend Hard and Soft Power" (Al-Monitor, 6 April 2014) <http://www.al-monitor.com/pulse/originals/2014/04/turkeyafrica-humanitarian-business-strategic-policy.html > accessed 21 September 2017. 
Turkish position. ${ }^{49}$ Although Turkey is now more determined to invest in Africa's energy industry, its interest in African energy sector is limited to a few initiatives, including the signing of energy cooperation agreements with a number of African countries and agreements to construct power stations in a few African countries which have not translated into large- scale projects or natural resource-related concessions.

Finally, Turkey's stance did not involve deals with SSA countries similar to those of BRICs, particularly Chinese "resource diplomacy". Another major difference between BRICS' and Turkish engagement in SSA is visible in the humanitarian field. BRICS' resort to global multilateral channels is opposed to Turkey's bilateral humanitarian diplomacy efforts. Moreover, the religious dimension of Turkish aid, provided especially through Diyanet and religiously-motivated NGOs, also differ from the involvement of BRICS operating bilaterally or through multilateral organizations.

This article has revealed that Turkish humanitarian aid and developmental support in SSA has been an important complement to official diplomatic and commercial efforts to further the country's political and economic interests. It has to be underlined that until recently, Turkish civil society and humanitarian NGOs have acted in tandem with governmental support rather than their roles directly resulting from the government policy. Furthermore, the article also compared the footprints of other emerging powers, such as BRICS in SSA, as well as their civil society and NGO participation as opposed to large-scale investments especially in natural resources and energy sectors. This reveals a huge contrast to the official rhetoric that characterizes Turkey's SSA engagement as a coherent one.

49 Turkish Ministry of Foreign Affairs, "Turkey-Africa: Solidarity and Partnership" <http://www.mfa.gov.tr/turkey_africa_-solidarity-and-partnership.en.mfa > accessed 14 April 2016. 